\title{
NOTES ON THE LANGUAGE OF THE EFA (PEOPLE) OR THE BINI COM- MONLY CALLED UZE ADO
}

As the Bini language has not yet been "put for book," many theories are rife as to its origin and relation to the Yoruba tongue. Some people have said that it is simply a dialect of Yoruba, but that it has no troublesome accents to be overcome, the intonation and accentuation of the Yoruba proving a great obstacle to the European who tries to learn that otherwise rather easy language. I suppose it was this hope of easily acquiring a language through which I might communicate with the natives of this country that determined me to make the attempt to master Bini. Alas, I have found it an almost impossible language to speak or write, for the Bini are just as particular about the way their words are accented as the Yoruba, and stare at you in wonder and anazement when you attempt to pronounce a word even just after they have said it ; and when you endeavour to write down a word at their dictation the struggle is beyond expression. You ask one person to utter the word distinctly, and you are satisfied that that word begins with the sound $n$; you ask a second person to say the word and you could stake your life that he commences the word with $l$. You repeat the word after your teachers, beginning it with either the $n$ or $l$, and they both stoop down nearer to your ear and certainly make a sound that you could easily take for either, and yet it should, you keep on thinking, be one or the other, and the subtle difference if you ponder over it drives you as near to madness as the thought of eternity does. The aspirate also is an "extra" beauty in the Bini tongue; it compares as badly in this as the English to the Italian.

The letters $p$ and $b$ in their connection with $g$ and $k$ as prefixes, and $w$ as an affix, are quite likely to drive the ordinary 
NOTES ON THE LANGUAGE OF THE EFA (PEOPLE) 143

individual into a state of excitement that he would do well to avoid. Of course when the sounds $g b, g p, k b$, and $k p$ come in the middle of a word the sounds are more or less clearly defined, but when these sounds commence a word it is ten chances to one that you miss them until they are found in the middle of a sentence, when the $g$ and $k$ sounds come out most unexpectedly. As to the $b w$ and prw sounds, I am satisfied that the $w$ sound is on occasions left out and in others put in for euphonistic reasons.

And when you have made a collection of a few words and ask for sentences composed of some of them, elision takes such a prominent part in them that you are prompted to give up your task in disgust.

As, however, the study of the language progresses, rules will be found out which may simplify matters, but will possibly destroy its apparently inconsistent native beauty and bind it up within sounds that are usually acknowledged as sufficient by ordinary twentieth century mortals. There is a prominent vowel sound in Bini, $\bar{o}$, which is pronounced like $o$ in "store" or aw in "law."

The infinitive prefix to verbs in the Bini is $n \delta$; thus to be is $n \delta r \bar{o}$; I am, me ro; igogo is smoke; nō gogo to smoke.

They say: (I) that before they learnt Yoruba the people spoke the language of Efa (the people); (2) that Yoruba was spoken by the higher classes until a patriotic king some two or three centuries ago tried to abolish it and forcer the nobles to speak Bini. We may conclude, therefore, that whatever the original language of the Efa may have been, its purity suffered from the invasion of the Yoruba language until it assumed towards it a similarity in construction.

The Jakri, although of Bini origin, having become a tribe of themselves at the time Yoruba was current and not having been influenced much by the revival of the language of $\mathrm{Efa}$, have gone on talking a bastard Yoruba.

A comparison between Bini, Jakri, and Yoruba words is therefore of some interest. The words given below have been corrected and recorrected so far as the Bini are concerned on three or four occasions, and may therefore be considered fairly but not definitely exact. Mr. M. J. Hughes, the grandson of a 
prince of Oyo, has kindly gone over the Jakri and Yoruba words, so that they may be looked upon as expressing the English words as exactly as possible.

The sentences collected may perhapg help the philologist to come to some conclusions as to the language of the Efa or people of what we now call the district of Bini in the western division of the Southern Nigeria Protectorate. The only other people talking a dialect of Efa are the people of the Esa country, generally called Ishan.

The people of Ora (= Kukuruku country) are said to understand more Bini than Yoruba, but the people of Ehan and the people of Ora understand one another's language, and the Ehán people are said to bear Yoruba. The Ehán people are partly under the government of the Lagos Protectorate and partly under that of Southern Nigeria.

$A d o$ is a form salutation derived possibly from the Portuguese word adews, or the French adiew, and has much the same meaning as the word $k \tilde{a} z y \delta$, a corruption of the Yoruba $k \delta r \delta$. Ado is common to the Bini and the Jakri, and one can easily understand how the Bini have got to be called $A d o$ by their facetious Sierra Leone chums. Two Binis meet, the one says ado (how do you do), the other answers ado (very well, thank you), and after a pause the latter returns the compliment ado (and how are you), the first one then answers ado (quite well, thank you), and after a pause again says ado (God bless you), ado (thank you) responds No. 2, and returns the blessing again by saying ado. This return of compliments is very pretty, if somewhat trying to the sense of humour of the wondering stranger, who has not yet learnt what an immense amount of meanings a word may have if only the correct intonation is given to it, and is apt to make some people suppose that ado is the beginning and end of the Bini language.

\section{Extract from letter by Mr. Dennett.}

[I have got at the following additional information:-

I was working at the seasons of the year, and had written down the names of the eight days of their week, etc. Then on questioning some natives as to the chalk marks on the earth in front of their jujus, they told me that the juju man did this 
NOTES ON THE LANGUAGE OF THE EFA (PEOPLE) 145

every fifth day, and they called the day Edeken (ede day, eke market). As they had not given me this as the name of any of the days of their week, all of which are now market days, I came to the conclusion that they must have some older week than that of eight days, so I asked them for the other days of their "juju" week, and they finally informed me that they were

$\begin{array}{ll}\text { Ed eken } & \text { I } \\ \text { Ed'aho } & 2 \\ \text { Ed'örie } & 3 \\ \text { Ed'okwo } & 4 \\ \text { Edeken } & 5 \text { and I, }\end{array}$

and after much trouble I discovered that each of the four great followers of Oba ${ }^{1}$ had a day of this juju week put apart for him.

This is one more link in the chain that I am weaving by which I hope to prove that long, long ago before these people were overrun by Yoruba and Muslims they had a religion almost identical with that of the Bantu of the Congo, and so possibly were Bantu. The leopard also they call the queen ogiame (bantu kama), while the Bantu call it ngo, and that is the name of the royal wife of Kongo. Another name for it is atalagba, and $t a$ they say is to shoot and gba to kill. And in the Kongo ta is also to shoot, to hunt, and now means also a gun, an onomatopoetic word perhaps derived from the noise made by the arrow as it whizzed through the air and hit its prey.]

\section{VOC A B U L A R Y.}

\section{GOD AND BEING.}

\begin{tabular}{|c|c|c|c|}
\hline English. & Bimi. & Jabri. & Yorwba. \\
\hline $\begin{array}{l}\text { To be } \\
\text { Being } \\
\text { Conicience } \\
\text { Spirit } \\
\text { God } \\
\text { Who? } \\
\text { Creator }\end{array}$ & $\begin{array}{l}\text { nō-ro } \\
\text { benfirye } \\
\text { afinme } \\
\text { orihon } \\
\text { osplubwe } \\
\text { ghenō } \\
\text { nolue }\end{array}$ & $\begin{array}{l}\text { munoron } \\
\text { iraye } \\
\text { aro ino } \\
\text { ojiji } \\
\text { oritche } \\
\text { nesi } \\
\text { toneye }\end{array}$ & $\begin{array}{l}\text { wa. } \\
\text { eda. } \\
\text { iyé. } \\
\text { ehu or emmi. } \\
\text { oloran. } \\
\text { tani. } \\
\text { eled. }\end{array}$ \\
\hline
\end{tabular}

1 On all his travels the oba was accompanied by foor great egãbu, just as the King of Lango was by his Mamhome, Mafuke, Mashienji, and Mankake. The names of these four were Iyase (home affairs, market), Osama (messenger and bargainer), Esogban (a kind of recurder and receiver of gifts, etc), and Esön (the captain or queller of disturbances). 


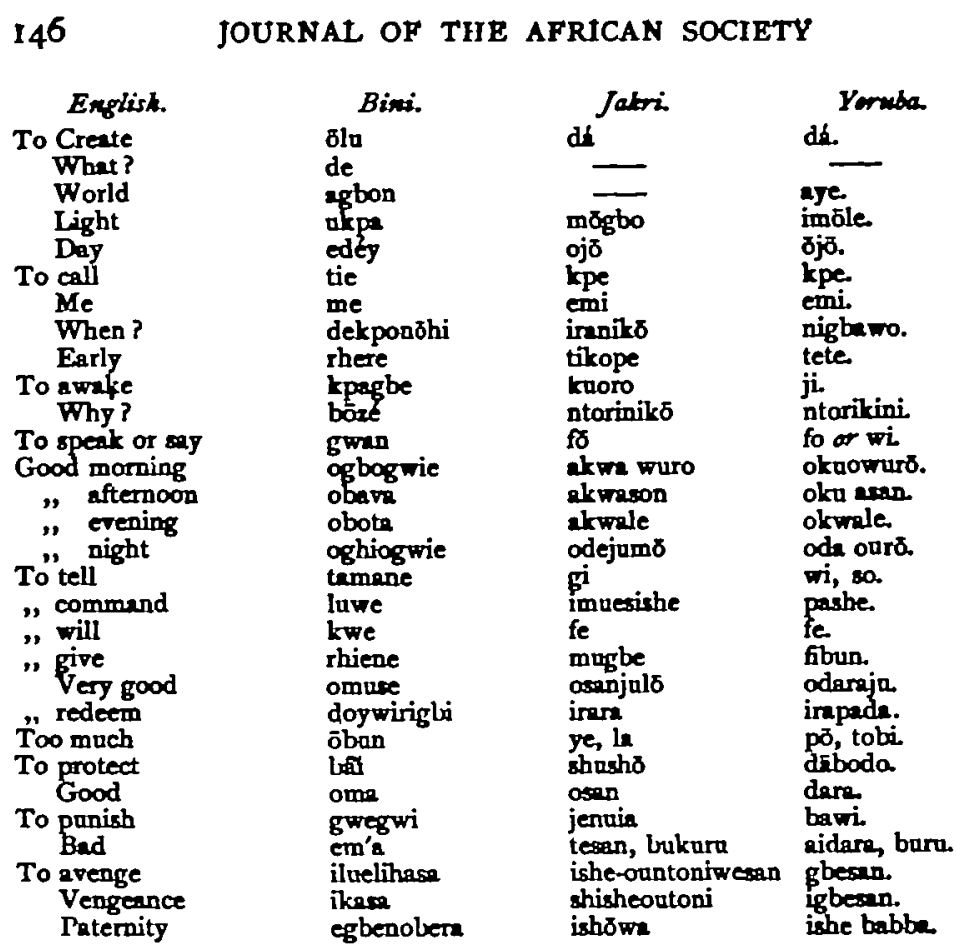

A FEw Bini Sentences.

\begin{tabular}{|c|c|}
\hline $\begin{array}{l}\text { God made the world } \\
\text { Keep my commandments } \\
\text { Give me a light } \\
\text { Punish that one } \\
\text { Who are you? } \\
\text { Speak to me } \\
\text { I do not wish to speak to you } \\
\text { I wish to speak to you } \\
\text { What, is that? } \\
\text { Whose is that? } \\
\text { Call ? } \\
\text { Wake me cerly } \\
\text { Do that ! } \\
\text { Do not do that }\end{array}$ & $\begin{array}{l}\text { Osalubwn mo agbon. } \\
\text { Tie ohi ma meme. } \\
\text { Rhi'nkpa me. } \\
\text { Iya'gbe. } \\
\text { Eghano? } \\
\text { Ga me gwan. } \\
\text { tho ni gwe gwan. } \\
\text { Tho ni gwe gwan. } \\
\text { Bwo naki? } \\
\text { Ghanari? } \\
\text { Tie re ri } \\
\text { Rherhed me. } \\
\text { Lqe! } \\
\text { Ge lwe. }\end{array}$ \\
\hline
\end{tabular}

Force, Liquids, Hearing.

\begin{tabular}{|c|c|c|c|}
\hline$E_{\text {mglish }}$ & Bini. & Jakri & Yoruba. \\
\hline $\begin{array}{l}\text { Maternity } \\
\text { Omnipotent. } \\
\text { Omnipotence } \\
\text { Virtue } \\
\text { To obey } \\
\text { Obedience } \\
\text { To serve }\end{array}$ & $\begin{array}{l}\text { egbenobiye } \\
\text { oma nó metia } \\
\text { etin } \\
\text { nohuman } \\
\text { hemoma } \\
\text { ihemoma }\end{array}$ & $\begin{array}{l}\text { iye } \\
\text { onieweni } \\
\text { oluodo } \\
\text { iwalosan } \\
\text { bbotagi } \\
\text { epboron } \\
\text { sen }\end{array}$ & $\begin{array}{l}\text { iya } \\
\text { odumare. } \\
\text { olvodumare. } \\
\text { iwaododo. } \\
\text { bawo. } \\
\text { ibawo. } \\
\text { sin. }\end{array}$ \\
\hline
\end{tabular}




Engtish.
Servant
Not
To falsify
Ear
To hear
To report
Mouth
To drink
Water
Fluid
To fill
", pour ort
" boil
", wesh
", bathe
Bath
Rain
River
To flow
", fish
Fisherman
Sea
Salt
Heaven
To blow
Wind
Mist
Smoke
To smoke
" smoke tobacco

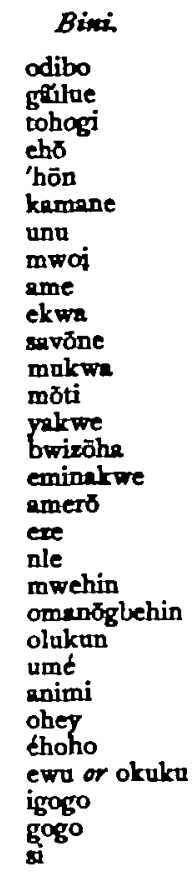

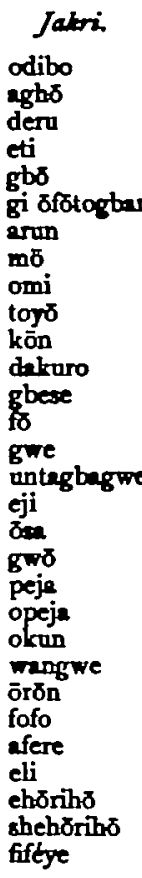

Yaruba.

odiba.

agbeds.

idern.

eti.

igbo.

rohin.

enu.

mu.

ami.

Yiȳ.

dekaro.

fo.

untafiwe

ojo.

oss.

shan.

peje.

opeja.

okun.

Yyo.

run.

fe.

afefe.

efi.

shefi.

finlefin.

Sentences in Bini.

The Creator is omnipotent

Report to me with your mouth what you hear with your ears

Water flow:

River water is sweet

Sea water is salt

Ejaw women fish

Will you serve me?

Do you hear ?

Come and fin me !

Bring water !

Pour it on my head

Wesh my feet

Fill the basin with water

Give me a drink of water

I am going to wash myself in the brook

Rob my back

Bring the kettle

Boil the water

The wind is blowing the smoke here

Will it min?

We want rain

Tordey

To-morrow

Yesterday

Nolue omobo werb wi

Gu me gwan bunwe be me 'na a hoyn b'ehb.

Ame lele or ologo le.

Ame'ze ori rihin.

Am'olukun om'ume.

Oho ceawn ga gbehin.

Wh ghin me?

U hoyn?

Do hoho ma fore !

Sa'me ri I

Iye namu humn.

Iye 'kbo' 'we mi

Sa'me v6n okpabo.

Sa'me me wan.

Me hiakwhe b'ex.

Pe mieke.

Makhe gume.

Mwan'me bixhix.

Ehoho ihoh' igogo re.

Ame ga'rd.

Ma hw'rme.

Ele.

Akwhe.

Node. 
SOLIDS, GROUND, REASON.

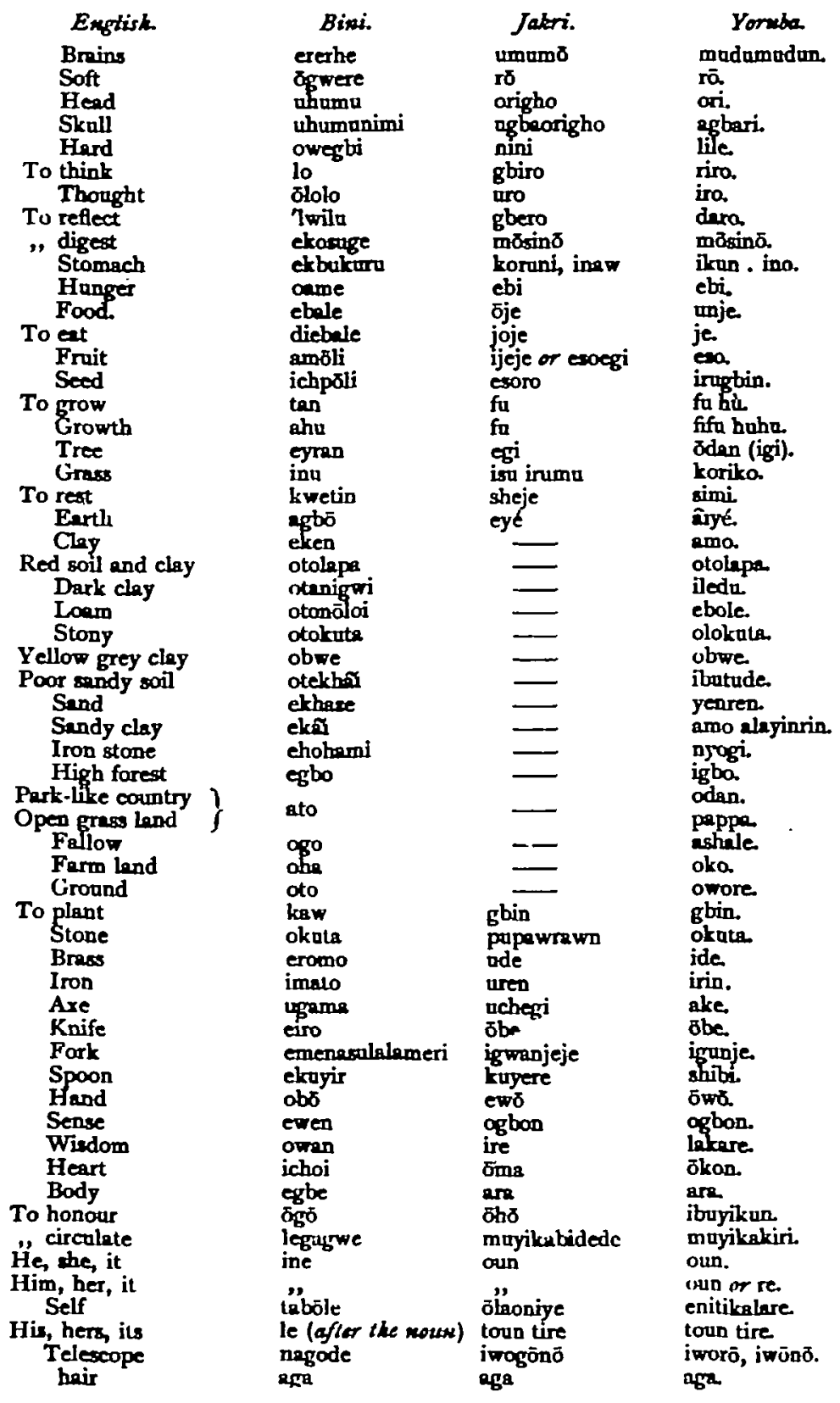


NOTES ON THE LANGUAGE OP THE EFA (PEOPLE)

English
Gun
Hammer
Book
To cut $\}_{\text {hrir }}$
Face
Skin
Hair
To brush
Beautiful
Ugly
To rot
Old
Kettle
Barin

Bini
ocisi
umomo
ebe
fian
fbe
haln
ichpapwegbi
etu
hiari
omose
ummammalo
ria
ommai
ahke
okpabo

Jakri
pakpa
metelo (Port.)
iwe
bu
da
eju
arabieran
iron
bele and kpupu
segwa
buruegwa
gbe
eligbo
utchi
igreju

Yomuba.

ibōn.

ikonsho.

iwe.

ge.

reja.

eran.

irun.

sha and gbon.

lewn.

buraewr.

re or gbe.

arugbo.

omi, koka.

Sentences in Bini.

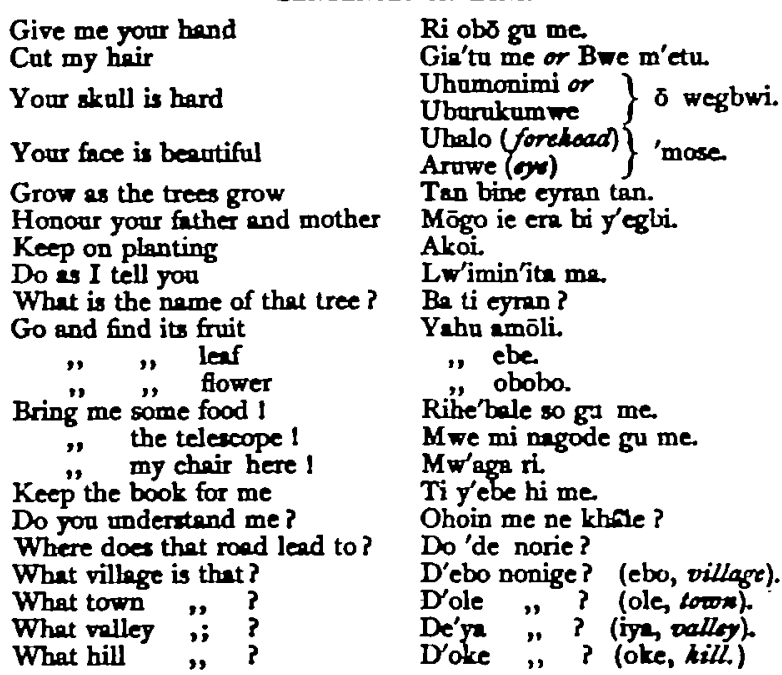

Female. Smell.

Ererlisk
Woman
Nose
Smell
To ",
Fire
Heat
To D"'
Desire
Hope
To ",
To love
To be naked
Womb
Marriage
Conceptiun

Bini.
oghwo
iwhe
gwiale
e"
ehren
moga
ö"
olwelo
lwelo
nogwobomase
nabanma
ohwei
iriohn
uhama

Jakri.
ebiren
imo
emi
gbemi
unm
gbo
dogbo
fife
igbejule
wiwn
otubiwoliwo
uliōmp
imuabitun
efu

Yoruba.
ubirin.
ma.
orun.
gborun.
no.
gbone.
gbone.
fe.
gbelele-ireti.
gbekele-reti.
miwn.
me ni ihoho.
indlemaw.
igbeynwo.
oyun.




Einglish
Fornication
Adnltery
Fear
Death
To kill
Seduction
To burn
" cook
Cook
To fry
" excite
" emit
" glimmer
Moor
Dark
To sleep
Bed
Bedroom
House
Door
Our
Ours
Table
We
Us
Often
To sit
Where
To sow
" plent

\begin{tabular}{|c|}
\hline 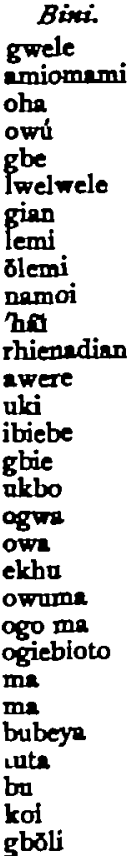 \\
\hline
\end{tabular}

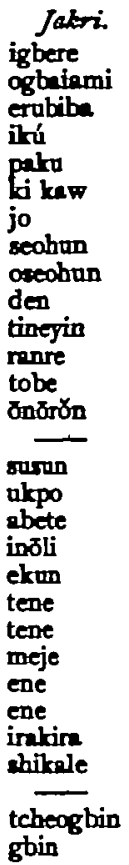

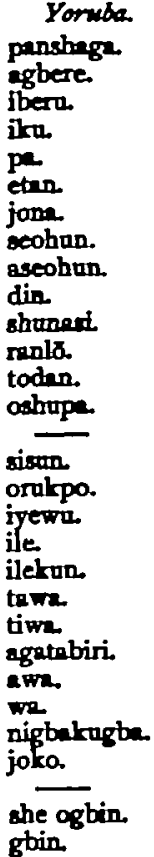

Sextences in Bini.

Wumen should marry and conceive Adultery means death

To smell is often to desiro

It smells good

Light the fire !

Cook my food I

Where is my chair?

I want to sit down

I do not want to sit down

I want to sleep

Keep quiet

Make my bed

Shut the door

Open the door

Oghwo ga newm'odo nu hame.

Amiomami owrí

Nogriale bubeyr i ma bo.

$O$ Fin' si.

O wia' kho.

Kokeren.

Ti hale me.

Aga me ba.

Tho ni tute.

'Tho ni tute.

Tho ni nobiex for noggbie.

Ghiơ home.

Do l'akbo me.

Ura.

Ki uro.

Male. Touch.

\section{English.}

To touch

Communication

Sensation

Penis

To spring

Germination

Production

Propagation
Bini.

ramoi

gie (sered)

ihoy

oranne

bie

r wibiekn
Jakri.

gbawobto

dapo, riranshe

ogbon

iyō

talewe

tofu

sisanun-tag bem ushe darepō
Yoruba.

kan.

idapd riranshe. ogbon mo.

okt.

she.

hiha.

eso, oun-ogbin.

atipösi. 
Notes on THE LANguage of THE EFA (PEOPLE) I 5 I

Engtish.
Motion
To go
To
To come
From
King
To rule
Prince
Chief
Father
Man
To know
" take
" steal
Theft
False witnes
Witmess
San
To shine
" absorb
Thander
Lightning
Black man
White man

Bini.
Iwegeyolegere
gia
ni
nari
ith
obe, ogie
kbinia
obiogie
ekhâ me
era.
omma
ne
rihele
ra
ra, oyi
tohoge
ose
ove
be
leyo
ova
onyanya
ommanikwhi
ommanofws

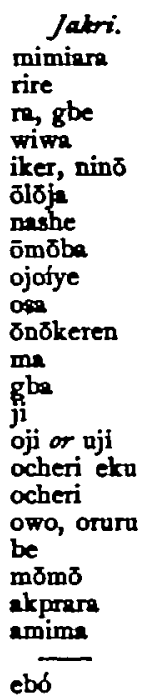

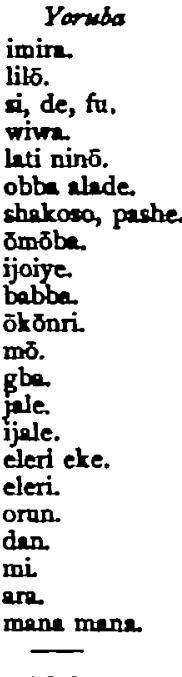

\section{SRntrnces in Bini.}

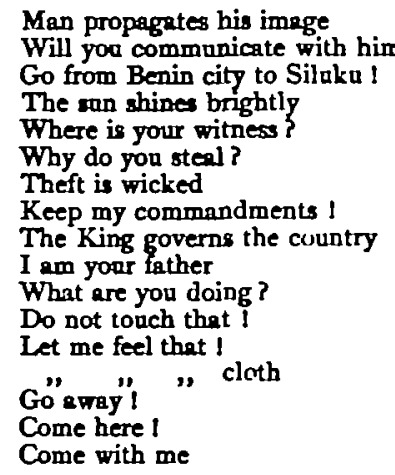

Omma nogbiye 'gbele.

Owa givuhuma gie.

Ke ado arie siluku !

Ove nyomu essesse.

Ose lu e bu ?

Boze nu narn?

Oyi olhu.

Rhie ohi me hi !

Ogie nonyriebo.

Wóri era mi.

Bwe la ?

Ge yu bó ra mō ni !

Gu me yobర nn mo !

K’"aba ": ri. rma'olron.

Nare or lare

Nare do lele me.

\section{ENERGY. Sight.}

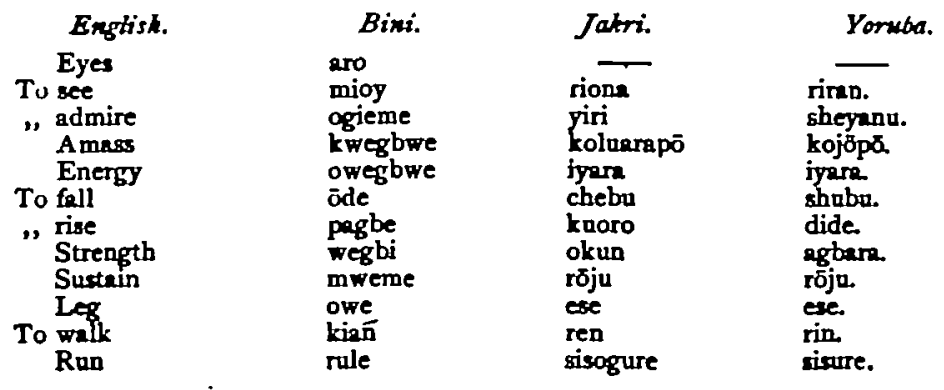




Engtish.
Dance
Slowiy
Quick
Dress
To use
Clothes
Coat
Shirt
Singlet
Trouser
Boots
To attract
Fascination
To cover ap
", hide

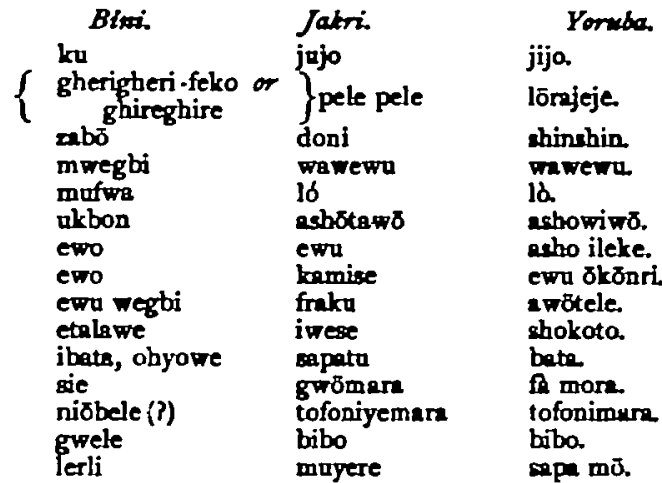

SENTENCEg IN BINI.

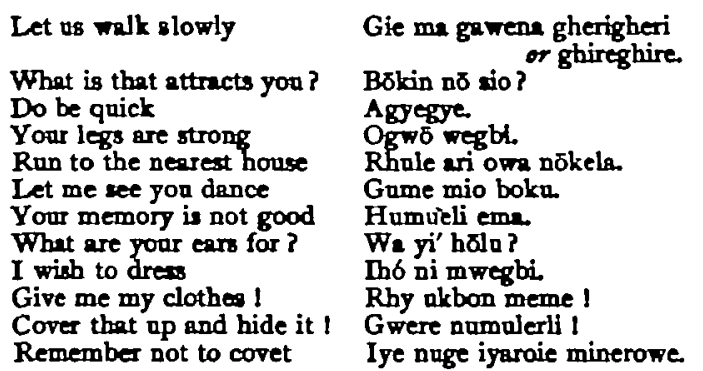

TASTE LIPS.

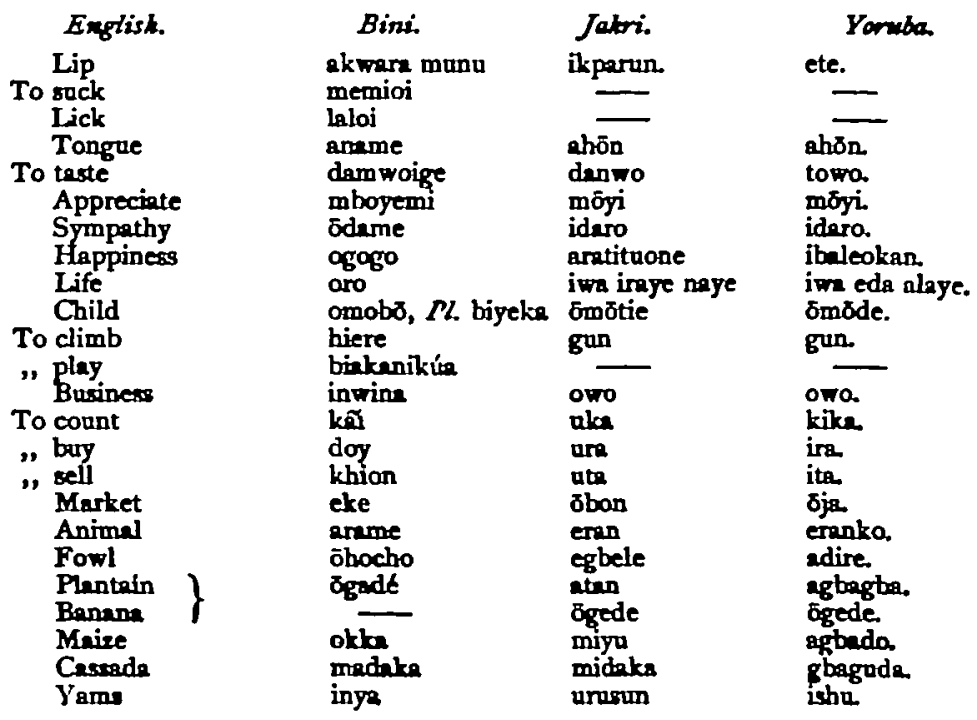




\begin{tabular}{|c|c|c|c|}
\hline $\begin{array}{l}\text { English. } \\
\text { Paupan } \\
\text { Oranges } \\
\text { Bread } \\
\text { Oil } \\
\text { Pepper } \\
\text { Sugar } \\
\text { Soup } \\
\text { Meat } \\
\text { Breakfast } \\
\text { Mid-diny meal } \\
\text { Evening ", }\end{array}$ & $\begin{array}{l}\quad \text { Bini. } \\
\text { uólo } \\
\text { alimai } \\
\text { emebo } \\
\text { ofebo } \\
\text { eyinhe } \\
\text { amwebo } \\
\text { umwome } \\
\text { emiyomo } \\
\text { ebalogrie } \\
\text { ebalava } \\
\text { ebalota }\end{array}$ & \begin{tabular}{l}
\multicolumn{1}{c}{ Jakn. } \\
ishin oyibo \\
osan \\
midaka \\
epo \\
ogolo \\
oyinba \\
igbagba \\
eran \\
oje owruro \\
oje oxan \\
oje ale
\end{tabular} & 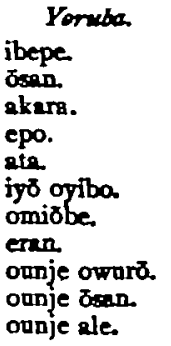 \\
\hline \multicolumn{4}{|c|}{ Sentrences in Bini. } \\
\hline \multicolumn{2}{|c|}{$\begin{array}{l}\text { Is breakfast ready? } \\
\text { When will dinner be ready? } \\
\text { let me taste that - } \\
\text { Please pass the - } \\
\text { We cannot live without food } \\
\text { Life (is a gift from) God } \\
\text { You must count those plants } \\
\text { It is happiness to have children } \\
\text { I appreciate your sympathy } \\
\text { Tall to me slowly }\end{array}$} & \multicolumn{2}{|c|}{ 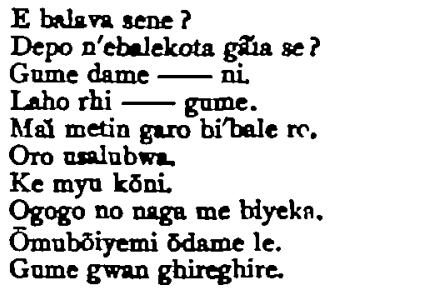 } \\
\hline \multicolumn{4}{|c|}{ Nōrō, to be. } \\
\hline $\begin{array}{l}\text { I em } \\
\text { Thou art } \\
\text { He is } \\
\text { We are } \\
\text { You are } \\
\text { They are }\end{array}$ & $\begin{array}{l}\text { me nỏ } \\
\text { we 'röd } \\
\text { ne 'ró } \\
\text { ma 'ró } \\
\text { we 'ró } \\
\text { ine 'ró }\end{array}$ & $\begin{array}{l}\text { I am not } \\
\text { Thon art not } \\
\text { He is not } \\
\text { We are not } \\
\text { You are not } \\
\text { They are not }\end{array}$ & $\begin{array}{l}\text { f ró } \\
\text { é rō. } \\
\text { é rō. } \\
\text { ma ro. } \\
\text { जa ro. } \\
\text { ind ró. }\end{array}$ \\
\hline I whs & me i'rō. & I should be & i ge ekre ro. \\
\hline $\begin{array}{l}\text { I will be } \\
\text { I may be }\end{array}$ & $\begin{array}{l}\text { i ga 'ro. } \\
\text { i ga ró. }\end{array}$ & $\begin{array}{l}\text { I should bare been } \\
\text { Be thut }\end{array}$ & $\begin{array}{l}\text { I ga ega ró. } \\
\text { ga me. }\end{array}$ \\
\hline
\end{tabular}

Nō me, to have.

\begin{tabular}{|c|c|c|c|}
\hline $\begin{array}{l}\text { I bave } \\
\text { Thou hast } \\
\text { He has } \\
\text { We have } \\
\text { You have } \\
\text { They have }\end{array}$ & $\begin{array}{l}\text { i me. } \\
\text { we me. } \\
\text { ne me. } \\
\text { mo me. } \\
\text { wa me. } \\
\text { in me. }\end{array}$ & $\begin{array}{l}\text { I have not } \\
\text { Thou hast not } \\
\text { He has not } \\
\text { We have not } \\
\text { Yoa have not } \\
\text { They bave not }\end{array}$ & $\begin{array}{l}\text { I me. } \\
\text { ve i me. } \\
\text { ne i me. } \\
\text { ma me. } \\
\text { wal me. } \\
\text { indi me. }\end{array}$ \\
\hline $\begin{array}{l}\text { I was having } \\
\text { I had } \\
\text { I will heve } \\
\text { I may bave }\end{array}$ & $\begin{array}{l}\text { i mō. } \\
\text { i ni k'og me. } \\
\text { i ga mō. } \\
\text { i ga me. }\end{array}$ & $\begin{array}{l}\text { I should heve } \\
\text { I should have had } \\
\text { Heve thoo }\end{array}$ & $\begin{array}{l}\text { i gn elwe me. } \\
\text { i ga git me. } \\
\text { me we. }\end{array}$ \\
\hline
\end{tabular}

